\title{
GLOBALIZATION, GENDER, AND RELIGION
}

\author{
T $\mathbb{H} \mathbb{E} \quad \mathrm{P} O \mathrm{~L} I \mathrm{~T}$ I C S O F \\ $\mathbb{W} O \mathbb{M} \mathbb{E} \mathbb{N}^{\prime} S \quad \mathbb{R} I \mathbb{H} \mathbb{T} S$ \\ $\mathbb{I} \mathbb{N} \quad \mathbb{A} \mathbb{T} \mathbb{H} O \mathbb{L} I \mathbb{C} A \mathbb{A}$ \\ $M \mathbb{U} S \mathbb{I} \mathbb{M} \quad \mathrm{CONTEXTS}$
}

\author{
EDITED BY \\ Jane H. Bayes \\ AND NAYereh ToHidi
}




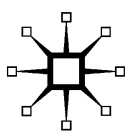

(C) Jane H. Bayes and Nayereh Tohidi 2001

Softcover reprint of the hardcover 1st edition 2001 978-0-333-94704-3

All rights reserved. No reproduction, copy or transmission of

this publication may be made without written permission.

No paragraph of this publication may be reproduced, copied or transmitted save with written permission or in accordance with the provisions of the Copyright, Designs and Patents Act 1988, or under the terms of any licence permitting limited copying issued by the Copyright Licensing Agency, 90 Tottenham Court Road, London W1T 4LP.

Any person who does any unauthorised act in relation to this publication may be liable to criminal prosecution and civil claims for damages.

The authors have asserted their rights to be identified as the authors of this work in accordance with the Copyright, Designs and Patents Act 1988.

Published by

PALGRAVE MACMILLAN

Houndmills, Basingstoke, Hampshire RG21 6XS and 175 Fifth Avenue, New York, N. Y. 10010

Companies and representatives throughout the world

PALGRAVE MACMILLAN is the global academic imprint of the Palgrave Macmillan division of St. Martin's Press, LLC and of Palgrave Macmillan Ltd. Macmillan ${ }^{\circledR}$ is a registered trademark in the United States, United Kingdom and other countries. Palgrave is a registered trademark in the European Union and other countries.

Outside North America

ISBN 978-1-349-66347-7

ISBN 978-1-137-04378-8 (eBook)

DOI 10.1007/978-1-137-04378-8

Inside North America

ISBN 978-0-312-22812-5 hardback

ISBN 978-0-312-29369-7 paperback

This book is printed on paper suitable for recycling and made from fully managed and sustained forest sources.

A catalogue record for this book is available from the British Library.

Library of Congress Catalog Card Number: 2001031735

Transferred to digital printing 2001 



\section{$C O \mathbb{N} \mathbb{E} \mathbb{N}$}

Acknowledgments

vii

List of Acronyms

Chapter 1 Introduction

Jane H. Bayes and Nayereh Tohidi

Chapter 2 Women Redefining Modernity and Religion in the Globalized Context

Nayereh Tohidi and Jane H. Bayes

Chapter 3 United States Catholic Women:

Feminist Theologies in Action

Susan Marie Maloney

Chapter 4 Implementing the Beijing

Commitments in Ireland

Yvonne Galligan and Nuala Ryan

Chapter 5. Implementing Women's Rights in Spain

107

Celia Valiente

Chapter 6. The Politics of Implementing Women's Rights in Catholic Countries of Latin America

Laura Guzmán Stein

Chapter 7 The Politics of Implementing

Women's Rights in Turkey

Ayşe Güneş-Ayata

Chapter 8. Women's Strategies in Iran from

the 1979 Revolution to 1999

Mehranguiz Kar

Chapter 9. The Politics of Implementing

Women's Rights in Bangladesh

Najma Chowdhury 
Chapter 10. The Silent Ayesha:

An Egyptian Narrative

Heba Raouf Ezzat

Appendix: A Brief Summary of Catholic and Muslim Expansion

Contributors

Index 



\section{ACKNOWLEDGMENTS}

he impetus for this book came from the United Nations Fourth World Conference on Women held in Beijing, China in 1995. Five

1 of our contributors attended the 1995 Beijing conference, two as members of their official government delegations, (Najma Chowdhury and Laura Guzmán Stein), and three as non-governmental organization (NGO) delegates (Ayşe Güneş-Ayata, Nayereh Tohidi, and Jane Bayes). Our first international gathering to discuss this project occurred in Seoul, Korea at the International Political Science Association meetings in July 1997. A second meeting occurred at the Middle-East Technical University in Ankara, Turkey in 1998. For financial and other support in making these meetings possible, we are grateful to the International Political Science Association, the Middle East Technical University, Ankara, and the College of Social and Behavioral Sciences and the College of the $\mathrm{Hu}$ manities at California State University, Northridge.

Many have contributed to this project other than those named. Shahla Sherkat joined us for our meetings in Turkey where she shared with us her experiences as founder and editor of the Iranian women's magazine, Zanan. As a Muslim feminist lawyer and advocate of human rights in Iran, Shirin Ebadi graciously responded to our queries about a number of legal and intellectual issues concerning the women's rights movement under the Islamic Republic of Iran. Eloise Buker of Denison College, Mary Hawkesworth of Rutgers University, and Rita Mae Kelly of the University of Texas read, critiqued, and made helpful suggestions for early versions of parts of the introductory chapters. The editors are most grateful to Linda Moody of Mills College, Elizabeth Say of California State University, Northridge, and Eloise Buker for their helpful comments, opinions, and suggestions on the later version of the two introductory chapters. To Nikki Keddie, we offer our special thanks for her careful and thoughtful reading of the manuscript and for her particularly insightful suggestions. Alana Powell, a graduate student at CSUN, was of invaluable service in helping to edit the manuscript as was Mahnaz Towhidi in helping with the 
translation of chapter 8 from Persian into English. This manuscript has also benefited from the feedback and comments we have received from our students who read some of the chapters before its final publication.

During the course of this project, one of our authors, Merhanguiz Kar, has been arrested, jailed, and charged with treason by the Iranian regime for her critique of the discriminatory laws against women and the violation of women's human rights under the Islamic Republic of Iran. She is currently released on bail and awaiting another trial in Iran. It is to her, her courage, her resilience, and her enormous contributions to the democracy movement in her own country, and to all the other brave and dedicated women in different parts of the world who are in the forefront of the struggle for women's human rights and empowerment, that we dedicate this book. 


\section{LIST OF ACRONYMS}

AIM

AVAW

AWGA

CEDAW

CFFC

CIDA

Col.

CONAPO

Conn.

CSW

DANIDA

DGPSW

DSCSD

EU

FGM

FWCW

HCCR

ICA

IPPF

IWO

NGO

Mass.

MEC

NGOPC
Action, Information, Motivation

Spanish central state policies against violence against women

Association of Women's Global Alliance

Convention for the Elimination of All Forms of Discrimination Against Women

Catholics for a Free Choice

Canadian International Development Agency

Colorado

National Committee on Population

Connecticut

United Nations Commission on the Legal and Social Status of Women

\section{Danish International Development Assistance}

Department General for the Problems and Status of Women

United Nations Department for Policy Coordination and Sustainable Development

European Union

Female Genital Mutilation

the United Nations Fourth World Conference on Women held in Beijing, China in 1995

High Council of Cultural Revolution

Irish Countrywomen's Association

International Family Planning Federation

Iranian Women's Organization

non-governmental organization

Massachussets

Ministry of Education and Culture

Bangladesh National Preparatory Committee Toward Beijing 


$\begin{array}{ll}\text { N.J. } & \text { New Jersey } \\ \text { N.Y. } & \text { New York } \\ \text { NWCI } & \text { National Women's Council of Ireland } \\ \text { PFA } & \text { Platform for Action at the United Nations Fourth World } \\ & \text { Congress on Women in Beijing in 1995 } \\ \text { PIOMH } & \text { Plan for Gender Equity Among Men and Women } \\ \text { PLAGE } & \text { Policy Leadership and Advocacy for Gender Equality } \\ \text { PLAU } & \text { Policy Leadership and Advocacy Unit } \\ \text { PREPCOM } & \text { United Nations Preparatory Committee for Fourth World } \\ & \text { Conference on Women } \\ \text { SNAT } & \text { Sectoral Needs Assessment Team } \\ \text { SNJM } & \text { Sisters of the Holy Names of Jesus and Mary } \\ \text { UK } & \text { United Kingdom } \\ \text { UN } & \text { United Nations } \\ \text { UNFPA } & \text { United Nations Fund for Population Activities } \\ \text { UNICEF } & \text { United Nations Children's Fund } \\ \text { USAID } & \text { United States Agency for International Development } \\ \text { USCC } & \text { United States Catholic Conference } \\ \text { WID } & \text { Women in International Development }\end{array}$

